(C) 2021 by the authors. This work is licensed under

Creative Commons Attribution 4.0 International License

https://creativecommons.org/licenses/by/4.0/

\title{
AUTOIMMUNE MYELOFIBROSIS ASSOCIATED WITH SYSTEMIC LUPUS ERYTHEMATOSUS: EXCEPTIONALLY RARE OR UNDERRECOGNIZED?
}

Received: April 30, 2021

Accepted: May 27, 2021

Döndü Üsküdar Cansu' ${ }^{1 *}$ https://orcid.org/0000-0001-6543-3905

Cengiz Korkmaz ${ }^{1}$ https://orcid.org/0000-0003-2679-0699

1Division of Rheumatology, Department of Internal Medicine, Faculty of Medicine, Eskişehir Osmangazi University, Eskişehir, Turkey

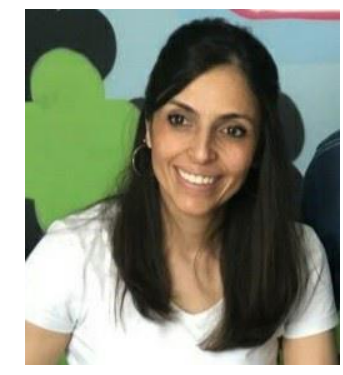

*Corresponding author: Döndü Üsküdar Cansu, MD, Professor, Department of Rheumatology, Faculty of Medicine, Eskişehir Osmangazi University, Eskisehir 26040, Turkey

Twitter handle: @dnd52298582; E-mail: ducansu@hotmail.com

\begin{abstract}
Systemic lupus erythematosus (SLE) is a chronic autoimmune disease which may involve several organs or organ systems. SLE may also have hematological as well as joint, kidney, and central nervous system involvements. Hematological abnormalities such as anemia, leukopenia, thrombocytopenia, and autoimmune hemolytic anemia are the best-known and most common hematological findings detected in SLE patients which are included in the classification criteria for SLE. Autoimmune myelofibrosis (AIMF) refers to bone marrow (BM) fibrosis (myelofibrosis) that develops in an autoimmune setting. Myelofibrosis is not among the SLE classification criteria and it is also not well-known. Current reports in the literature on SLE-associated AIMF are mostly restricted to case reports or reviews of such case reports. The occurrence of BM fibrosis in SLE patients has been explored merely in few studies which concluded that myelofibrosis is a rare symptom of SLE. Herein, we propose the hypothesis that SLE-associated AIMF is not rare and, on the contrary, it can indeed be more frequent than what is known or expected.
\end{abstract}

Keywords: Systemic lupus erythematosus, Autoimmune myelofibrosis, Hematological involvement

How to cite: Üsküdar Cansu D, Korkmaz C. Autoimmune myelofibrosis associated with systemic lupus erythematosus: Exceptionally rare or underrecognized? Cent Asian J Med Hypotheses Ethics 2021:2(2):96-100. https://doi.org/10.47316/caimhe.2021.2.2.04

\section{INTRODUCTION}

Systemic lupus erythematosus (SLE) is a systemic autoimmune disease of unclear etiology that is usually characterized by autoantibody production. However, SLE can also manifest itself with heterogeneous clinical features including multisystem involvement. The prevalence of SLE can vary between different ethnic populations [1]. Conditions manifesting with peripheral cytopenia such as anemia, leukopenia or lymphopenia, and thrombocytopenia are common hematological findings of SLE which can be immune-mediated or caused by other factors [2]. Moreover, thrombotic thrombocytopenic purpura and myelofibrosis are described as other rare hematological abnormalities of SLE [3]. Myelofibrosis is a histological finding characterized by bone marrow (BM) fibrosis in combination with clonal proliferation of myeloid stem cells which may develop in various diseases including malignancies, endocrine disorders, autoimmune disease, and infections. Autoimmune myelofibrosis (AIMF) is a rare variety of myelofibrosis. AIMF may either be secondary to a described autoimmune disease (secondary AIMF) or primary in the absence of a clinically diagnosed autoimmune disease, but in the 
presence of serological evidence for autoantibodies (primary AIMF) $[3,4]$.

Peripheral cytopenia is an established criterion for SLE classification [5]. Although the BM is a target organ in SLE, this has not yet been extensively addressed in the medical literature [6-9]. Recognition of myelofibrosis as a cause of SLE-associated peripheral cytopenia is a (partially) novel concept [3]. However, myelofibrosis is not incorporated into the classification criteria for SLE. In a literature review published in 2015, a thorough assessment of hematological involvement in SLE suggested that myelofibrosis is a definitive finding of SLE, albeit its rare occurrence [3]. Current reports in the literature on BM fibrosis in the context of SLE are usually presented as case reports or reviews of such case reports [10-18]. The occurrence of BM fibrosis in SLE patients has been explored merely in few studies [6-9, 19].

\section{HYPOTHESIS}

Our hypothesis in this study assumes that SLEassociated AIMF is not rare and, on the contrary, it can indeed be more frequent than what is known or expected. Herein, we have structured our hypothesis based on the recommendations entitled "Scientific Hypotheses: Writing, Promoting, and Predicting Implications" [20]. Our aim is to explain our suggestions by delving into the limited number of previous publications on the subject matter to help find answers for certain questions and thus provide evidence.

\section{TESTING THE HYPOTHESIS}

\section{The concept of AIMF is not a well-known entity}

AIMF terminology: Myelofibrosis is a rare cause of AIMF and usually co-exists with other autoimmune diseases such as SLE and rheumatoid arthritis. Myelofibrosis is called secondary AIMF when it is associated with a defined autoimmune disease; AIMF is used in the absence of a primary autoimmune disease to trigger myelofibrosis, but in the presence of serological evidence for autoimmunity [4]. Evaluating their own SLE cases and formerly reported SLE cases, Paquette and colleagues have argued that an autoimmune disease may play a role in the occurrence of myelofibrosis and thus coined the term "AIMF" to represent such cases [21]. Hence, the term primary myelofibrosis (PMF) corresponds to myeloproliferative diseases, and apart from them AIMF is classified as primary or secondary [4].

\section{SLE accompanied by cytopenia usually warrants} the collaboration of rheumatologists and hematologists. In case BM examination is needed as part of the cytopenia workup, no indications have been elaborated thus far for deciding on patient eligibility for BM examination. During the course of SLE, upon the tendency to attribute cytopenia to this disease, corticosteroid or immunosuppressive therapy is usually initiated and a response is achieved in majority of the cases [3]. At times, hematological involvements presenting during the course of SLE can be followed up by hematologists rather than by rheumatologists. In the event that the center where an attending rheumatologist is employed does not/cannot perform or underperforms BM examination in SLE patients with cytopenia, then, it is likely to yield no or less diagnosis of AIMF. In rheumatology practice, no indications or criteria have been outlined to guide BM biopsy particularly for SLE patients with cytopenia [6-9]. This may eventually result in a smaller number of SLE patients undergoing BM examination than the required number, and in turn only a smaller subset of patients is diagnosed than the number of patients who could actually be diagnosed with AIMF if they would undergo BM examination.

\section{Is it likely that BM examination is performed less} often than required as it is an invasive diagnostic method? AIMF diagnosis relies on the morphological features as detected in BM examination. Presently, the gold standard is biopsy, an invasive diagnostic method. Only recently, several biomarkers have been introduced for PMF [22, 23]. On the other hand, no biomarker has been identified to date for AIMF or SLE-associated AIMF. Possibly, the biomarker(s) to be specified by future research may help us spare patients from invasive BM biopsy, and the resulting ease of diagnosis could increase the rate of newly diagnosed cases.

\section{There are no definitely established diagnostic criteria for AIMF}

Pullarkat et al. [24] have suggested the diagnostic criteria for primary AIMF, whereas Vergara-Lluri et al. [18] put forward morphological criteria in BM biopsy for secondary AIMF based on their study population, $69 \%$ of which is composed of autoimmune diseases. As such, they have described 7 morphological criteria: 1) Rarity or absence of a leucoerythroblastic reaction; 2) Absence of peripheral eosinophilia or basophilia; 3) Mild degree of BM fibrosis [usually slight reticulin fibrosis (myelofibrosis 1)]; 4) Absence of osteosclerosis and bone changes; 5 ) Presence of hypercellular BM characterized by erythroid and megakaryocytic hyperplasia; 6) Presence of lymphoid aggregates; 7) Absence of dysplastic features particularly in megakaryocytes $[4,18,24]$. The diagnosis requires fulfillment of all criteria. Nevertheless, an SLE patient may probably have AIMF even in the presence of less than the 7 morphological criteria which might be a 
factor to blame as to why AIMF is underdiagnosed. Of note, no precise diagnostic criteria have been stated to date for primary AIMF or secondary AIMF which encompasses SLE-associated AIMF. Therefore, the lack of well-established diagnostic criteria for AIMF can be another factor leading to the underestimation of AIMF and hindering the definitive diagnosis of AIMF which (may) coexist with SLE.

\section{The perception that SLE-associated AIMF is rare}

The initial reports in the medical literature on SLEassociated AIMF have a span of nomenclature [25]. Paquette et al. have coined the term AIMF [21]. As of the 1990s up until now, case reports or case-based reviews have predominantly been published in this field [10-18, 24]. Just a small number of studies have investigated BM in SLE cases [6-9]. Several studies aimed at the etiological characterization of AIMF, and SLE association was ranked as the most frequent cause in such works $[18,19]$. The prevalence of SLE-associated AIMF, however, remains unclear. The discrepancy among the methodologies applied in the studies is one of the key factors affecting the results. In a study including 41 SLE patients with cytopenia, BM examinations of the patients have revealed myelofibrosis in $5 \%$, whereas in another study evaluating 21 cytopenic SLE patients who were not receiving immunosuppressive treatment, the myelofibrosis ratio was $76 \%$ [7,9]. Likewise, myelofibrosis was found in $80 \%$ of the patients in a study which recruited 40 SLE patients with unexplained cytopenia, and the figure specified for SLE-associated AIMF was $70.7 \%$ in another study where the researchers similarly conducted BM biopsy due to cytopenia $[6,8]$. Taken together, these studies imply that SLE-associated AIMF per se is much more common. Yet another factor resulting in myelofibrosis that can be overlooked could be the fact that clinicians do not alert pathologists to pay additional diligence in taking myelofibrosis into consideration and, therefore, appropriate means of pathological examinations are not utilized.

\section{CONCLUSION}

Although AIMF is rarely reported in SLE patients, its prevalence appears to be higher than what is known. Provided that a BM examination can be carried out for each cytopenic SLE patient, then AIMF would be determined and would no longer be accepted as a rare condition. Rheumatologists taking care of SLE patients should keep the likelihood of AIMF in mind in the event of hematological involvement. Clinicians should not hesitate to perform BM biopsy even if it is invasive in eligible patients in an attempt to definitively diagnose SLE-associated AIMF, unless a biomarker is described for this purpose. We are not sure whether ethnic differences or different geographic features play a role in the development of AIMF. Therefore, studies involving different ethnic groups will provide additional information on this subject.

\section{FUNDING}

None

\section{AUTHOR CONTRIBUTIONS}

Conception and design of the hypothesis: DUC; Drafting of the manuscript: DUC and CK; Critical revision of the manuscript: DUC and CK; Approval the final version to be submitted: DUC and CK.

\section{CONFLICTS OF INTEREST}

Both authors have completed the ICMJE Disclosure Form (http://www.icmje.org/disclosure-of-interest); available on request from the correspodning author). Both authors declare that there are no potential conflicts of interest to disclose.

\section{DISCLAIMER}

No part of this article is copied or published elsewhere. The hypotheses includes the original opinion of the authors in view of the evidence synthesis.

\section{REFERENCES}

1. Nasonov E, Soloviev S, Davidson JE, Lila A, Ivanova R, Togizbayev G, et al. The prevalence and incidence of systemic lupus erythematosus (SLE) in selected cities from three Commonwealth of Independent States countries (the Russian Federation, Ukraine and Kazakhstan). Lupus 2014;23(2):213-219.

2. Vasudevan AR, Ginzler EM. Clinical features of systemic lupus erythematosus. In: Hochberg MC, Silman AJ, Smolen JS, Weinblatt ME, Weisman MH (eds). Rheumatology, 5th edition, Elsevier, Philadelphia, 2011;12291246.

3. Fayyaz A, Igoe A, Kurien BT, Danda D, James JA, Stafford HA, et al. Haematological manifestations of lupus. Lupus Sci Med 2015;2(1):e000078.

4. Marcellino B, El Jamal SM, Mascarenhas JO. Distinguishing autoimmune myelofibrosis from primary myelofibrosis. Clin Adv Hematol Oncol 2018;16(9):619-626. 
5. Hochberg MC. Updating the American College of Rheumatology revised criteria for the classification of systemic lupus erythematosus [letter]. Arthritis Rheum 1997;40(9):1725.

6. Voulgarelis M, Giannouli S, Tasidou A, Anagnostou D, Ziakas PD, Tzioufas AG. Bone marrow histological findings in systemic lupus erythematosus with hematologic abnormalities: a clinicopathological study. Am J Hematol 2006;81(8):590-597.

7. Pereira RM, Velloso ER, Menezes Y, Gualandro S, Vassalo J, Yoshinari NH. Bone marrow findings in systemic lupus erythematosus patients with peripheral cytopenias. Clin Rheumatol 1998;17(3):219-222.

8. Üsküdar Cansu D, Üsküdar Teke H, Işiksoy S, Korkmaz C. Bone marrow as a target organ of systemic lupus erythematosus: analysis of cases with myelofibrosis. Int J Rheum Dis 2018;21(5):1049-1059.

9. Wanitpongpun C, Teawtrakul N, Mahakkanukrauh A, Siritunyaporn S, Sirijerachai C, Chansung K. Bone marrow abnormalities in systemic lupus erythematosus with peripheral cytopenia. Clin Exp Rheumatol 2012;30(6):825829.

10. Ungprasert $P$, Chowdhary VR, Davis MD, Makol A. Autoimmune myelofibrosis with pancytopenia as a presenting manifestation of systemic lupus erythematosus responsive to mycophenolate mofetil. Lupus 2016;25(4):427-430.

11. Belfeki N, Shankarasivam G, Declerck D, Diamantis S. Autoimmune myelofibrosis: a rare haematological involvement in systemic lupus erythematosus. BMJ Case Rep 2019;12(1):bcr-2018-227520.

12. Cansu DÜ, Teke HÜ, Korkmaz C. A rare cause of cytopenia in a patient with systemic lupus erythematosus: autoimmune myelofibrosis. Eur J Rheumatol 2017;4(1):76-78.

13. Mbonu I, Sossou C, Nnaoma CB, Sun X, Schleicher L, Xiong W. A case of systemic lupus erythematosus presenting as autoimmune myelofibrosis. Am J Case Rep 2019;20:937-940.

14. Wibowo T, Kawada S, Ishida Y, Yoshimine Y, Ishikawa N, Kawamoto K, et al. Autoimmune myelofibrosis associated with systemic lupus erythematosus: a case report. Mod Rheumatol Case Rep 2020;4(1):28-33.

15. Chalayer $E$, Ffrench $M$, Cathébras $P$. Bone marrow fibrosis as a feature of systemic lupus erythematosus: a case report and literature review. Springerplus 2014;3:349.

16. Del Porto F, Tatarelli C, Di Napoli A, Proietta M. Systemic lupus erythematosus and myelofibrosis: A case report and revision of literature. Leuk Res Rep 2018;9:58-64.

17. Koduri PR, Parvez M, Kaza S, Vanajakshi S. Autoimmune myelofibrosis in systemic lupus erythematosus report of two cases and review of the literature. Indian J Hematol Blood Transfus 2016;32(3):368-373.

18. Vergara-Lluri ME, Piatek Cl, Pullarkat V, Siddiqi IN, O'Connell C, Feinstein DI, et al. Autoimmune myelofibrosis: an update on morphologic features in 29 cases and review of the literature. Hum Pathol 2014;45(11):2183-2191.

19. Mertz $P$, Chalayer E, Amoura Z, Cathebras $P$, Chiche L, Coestedoat N, et al. Clinical spectrum and therapeutic management of auto-immune myelofibrosis: a nation-wide study of 30 cases. Haematologica 2021;106(3):871874.

20. Gasparyan AY, Ayvazyan L, Mukanova U, Yessirkepov M, Kitas GD. Scientific hypotheses: Writing, promoting, and predicting implications. J Korean Med Sci 2019;34(45):e300.

21. Paquette RL, Meshkinpour A, Rosen PJ. Autoimmune myelofibrosis. A steroid-responsive cause of bone marrow fibrosis associated with systemic lupus erythematosus. Medicine (Baltimore) 1994;73(3):145-152.

22. Bjørn ME, Andersen CL, Jensen MK, Hasselbalch HC. Circulating YKL-40 in myelofibrosis a potential novel biomarker of disease activity and the inflammatory state. Eur J Haematol 2014;93(3):224-228.

23. Lally J, Boasman K, Brown L, Martinelli V, Cappuccio I, Sovani V, et al. GATA-1: a potential novel biomarker for the differentiation of essential thrombocythemia and myelofibrosis. J Thromb Haemost 2019;17(6):896-900.

24. Pullarkat V, Bass RD, Gong JZ, Feinstein DI, Brynes RK. Primary autoimmune myelofibrosis: definition of a distinct clinicopathologic syndrome. Am J Hematol 2003;72(1):8-12.

25. Daly HM, Scott GL. Myelofibrosis as a cause of pancytopenia in systemic lupus erythematosus. J Clin Pathol 1983;36(11):1219-1222. 


\section{ЖҮЙЕЛІ ҚЫЗЫЛ ЖЕГІМЕН БАЙЛАНЫСТЫ АУТОИММУНДЫҚ МИЕЛОФИБРОЗ: ӨТЕ СИРЕК КЕЗДЕСІП, НАШАР АНЫҚТАЛАДЫ МА?}

\section{Түйіндеме}

Жүйелі қызыл жегі (ЖҚЖ) - созылмалы аутоиммунды ауру, бір уақытта әр түрлі мүшелер мен мүшелер жүйесіне әсер етеді. ЖҚЖ гематологиялық зақымданулармен, буындардың, бүйректердің және орталық жүйке жүйесінің зақымдалуымен бірге өтеді. Анемия, лейкопения, тромбоцитопения және аутоиммунды гемолитикалық анемия сияқты гематологиялық ауытқулар емделушілердегі ЖҚЖ-ның жақсы зерттелген және ең көп таралған гематологиялық белгілері саналып, осы аурудың жіктелу өлшемшарттары болып табылады. Аутоиммунды миелофиброз аутоиммунды аурулар кезінде дамитын сүйек кемігінің (миелофиброз) фиброзына жатады. Қазіргі таңда миелофиброз ЖҚЖ-ның жіктелуіне арналған өлшемшарттарына кірмейді және аз зерттелген. ЖҚЖ-ның байланысты аутоиммунды миелофиброзға арналған қолданыстағы әдебиеттер жағдайларды сипаттаумен немесе шолумен ғана шектеледі. ЖҚЖ-ға шалдыққан науқастарда сүйек кемігінің фиброзының пайда болуы бірнеше зерттеулерде ғана зерттелген, олар миелофиброз ЖҚЖ-ның сирек кездесетін белгісі болып табылады деген қорытындыға келді. Бұл мақалада авторлар ЖҚЖ-мен байланысты аутоиммунды миелофиброз сирек кездеспейтін және қазіргі таңда белгілі немесе болжамнан да жиі кездесуі мүмкін деген гипотеза ұсынуда.

Түйінді сөздер: жүйелі қызыл жегі, аутоиммунды миелофиброз, гематологиялық зақымданулар. Дәйексөз үшін: Ускюдар Джансу Д., Коркмаз К. Жүйелі қызыл жегімен байланысты аутоиммундық миелофиброз: өте сирек кездесіп, нашар анықталады ма? Медициналық гипотеза мен этиканың Орта Азиялық журналы.2021;2(2):96-100. https://doi.org/10.47316/cajmhe.2021.2.2.04

\section{АУТОИММУННЫЙ МИЕЛОФИБРОЗ, СВЯЗАННЫЙ С СИСТЕМНОЙ КРАСНОЙ ВОЛЧАНКОЙ: КРАЙНЕ РЕДКИЙ И ПЛОХО ВЫЯВЛЯЕМЫЙ?}

\section{Резюме}

Системная красная волчанка (СКB) - это хроническое аутоиммунное заболевание, которое вовлекает одновременно отдельные органы или системы органов. СКВ также может сопровождаться гематологическими поражениями, как и поражениями суставов, почек и центральной нервной системы. Такие гематологические аномалии как анемия, лейкопения, тромбоцитопения и аутоиммунная гемолитическая анемия, являются хорошо изученными и наиболее распространенными гематологическими признаками СКВ у пациентов, они являются критериями классификации данного заболевания. Аутоиммунный миелофиброз относится к фиброзу костного мозга (миелофиброзу), который развивается при аутоиммунных заболеваниях. На данный момент миелофиброз не относится к критериям для классификации СКВ и малоизучен. Имеющиеся литературные источники, посвященные аутоиммунному миелофиброзу, связанному с СКВ, ограничиваются описаниями случаев или обзорами случаев. Возникновение фиброза костного мозга у пациентов с СКВ было изучено лишь в нескольких исследованиях, которые пришли к выводу, что миелофиброз является редким симптомом СКВ. В данной статье авторы выдвигают гипотезу о том, что аутоиммунный миелофиброз, ассоциированный с СKВ, не является редким и может встречаться чаще, чем на данный момент известно или прогнозируется.

Ключевые слова: системная красная волчанка, аутоиммунный миелофиброз, гематологические поражения.

Для цитирования: Ускюдар Джансу Д., Коркмаз К. Аутоиммунный миелофиброз, связанный с системной красной волчанкой: встречается крайне редко или не признается? Центральноазиатский журнал медицинских гипотез и этики. 2021;2(2):96-100. https://doi.org/10.47316/cajmhe.2021.2.2.04 